\title{
METODE TA'BIR ASH-SHUWAR AL-'ASYWAI: INOVASI PEMBELAJARAN MAHARAH KALAM MAHASISWA PENDIDIKAN BAHASA ARAB IAIN MADURA
}

\author{
Khoirul Bariyah \\ Magister UIN Maulana Malik Ibrahim Malang \\ kbariyah91@gmail.com \\ Muassomah Muassomah \\ UIN Maulana Malik IbrahimMalang \\ muassomah@bsa.uin-malang.ac.id
}

\begin{abstract}
Maharah Kalam (Speaking Skill) is ability to express articulation sound or word to express mind of idea, opinion, wishing or feeling with oral to other people. Speaking Skill in Arabic language part of based skill so university student able to the skill, in other hand part of them make speaking difficuality in Arabic language, couse by self confidence and difficult to speaking memorized mufrodat (the verb), etc. Because of this, as the teacher have many methods and used some of methods in learning become efectif, one of methods is Ta'bir Ash-Shuwar Al-'Asywai or known as story telling is describe picture with rearrange picture in jumble and appropriate with observation by researcher. Researcher observing toward student grade III in IAIN Madura getting increase speaking skill and interest with Maharah Kalam/Speaking Skill.
\end{abstract}

\section{Keywords : Speaking Skill, Ta'bir Ash-Shuwar Al-'Asywai Method, Learning Process}

\begin{abstract}
ABSTRAK : Maharah kalam (Keterampilan berbicara) adalah kemampuan mengungkapkan bunyi-bunyi artikulasi atau kata-kata untuk mengekspresikan pikiran berupa ide, pendapat, keinginan, atau perasaan secara lisan kepada mitra pembicara. Maharah kalam dalam konteks Bahasa arab merupakan salah satu keterampilan yang menjadi dasar utama dalam Bahasa Arab, sehingga mahasiswa wajib menguasainya. Namun, sebagian besar mahasiswa mengalami kesulitan dalam berbicara Bahasa Arab yang mayoritas disebabkan oleh faktor ketidak percayaan diri mereka dalam berbicara Bahasa arab, kurangnya penguasaan mufrodat, dan lain sebagainya. Oleh karena itu, sebagai pengajar harus menguasai berbagai metode dan menggunakan beberapa metode agar pembelajaran menjadi efektif, salah satunya menggunakan metode Ta'bir Ash-Shuwar Al-'Asywai atau dikenal dengan metode story telling menggunakan media gambar seri. Yang mana metode tersebut yaitu metode yang mendiskripsikan atau menceritakan gambar yang telah di susun dari gambar yang di acak. dan sesuai dengan observasi yang dilakukan oleh peneliti, bahwa dengan metode dan media ynag diterapkan oleh peneliti terhadap mahasiswa semester III Jurusan Pendidikan Bahasa Aarab di IAIN Madura dapat meningkatkan ketrampilan berbicara dan meningkatkan minat mereka dalam pembelajaran maharaha kalam.
\end{abstract}

Kata Kunci : Maharah Kalam, Metode Ta'bir Ash-Shuwar Al-'Aswai, Proses Pembelajaran. 


\section{PENDAHULUAN}

Maharah Kalam adalah salah satu maharah/ keterampilan yang sangat penting dalam Bahasa arab. Sebab berbicara merupakan bagian dari keterampilan yang dipelajari oleh pengajar, sehungga maharah kalam dianggap sebagai bagian yang sangat mendasar dalam mempelajari Bahasa asing. Secara Umum keterampilan berbicara bertujuan agar para pelajar mampu berkomunikasi dengan baik dan wajar .1 Oleh karena itu, Dalam pembelajaran maharah kalam terdapat berbagai macam metode agar pelajar merasa senang dalam pembelajaran tersebut. Salah satunya yaitu metode Ta'bir Ash-shuwar Al-'Asywai atau dikenal dengan story telling dengan media gambar seri. Metode Ta'bir Ash-shuwar Al'Asywai ini merupakan metode yang sangat efektif untuk diterapkan pada mahasiswa semester III jurusan pendidikan Bahasa arab. Karena dengan latar belakang belakang mahasiswa yang berbeda-beda dan sesuai fakta dilapangan kurangnya minat mahasiswa pada pembelajaran maharah kalam yang disebabkan oleh anggapan mereka terhadap sulitnya dalam berbicara atau berdialog menggunakan Bahasa Arab.

Keterampilan berbicara juga merupakan keterampilan dalam melakukan pola-pola tingkah laku untuk penyampaian suatu maksud seseorang kepada orang lain dengan menggunakan Bahasa lisan sehingga maksud tersebut dapat dipahami oleh orang lain dan mencapai tujuan tertentu. ${ }^{2}$ Keterampilan berbicara ini dapat dicapai melalui beberapa latihan (praktik) dari apa yang didengar secara pasif dalam latihan mendengar. ${ }^{3}$ Tanpa latihan lisan secara intensif, maka sangat sulit bagi mahasiswa untuk mencapai penguasaan Bahasa Arab secara sempurna.

Dalam maharah kalam juga terdapat masalah-masalah yang dihadapi dalam pembelajarannya yaitu : 1) Siswa grogi karena khawatir melakukan kesalahan, takut di kritik dan malu, 2) Tidak ada bahan untuk dibicarakan, 3)

\footnotetext{
${ }^{1}$ Minatul Azmi dan Maulida Puspita, "Metode Story Telling Sebagai Solusi Pembelajaran Maharah Kalam di PKPBA UIN Malang", Inovasi Media Pembelajaran Bahasa, Sastra, dan Budaya Arab, Seminar Nasional Bahasa Arab Mahasiswa Iii Thaun 2019 HMJ Jurusan Sastra Arab Fakultas Sastra Universitas Negeri Malang, 73.

${ }^{2}$ Ni Kd. Dewi Wahyuni, Wyn. Wiarta, Ngh. Suadnyana, "Penerapan metode bercerita berbantuan media gambar seri untuk meningkatkan keterampilan berbicara anak kelompok B TK Putra Sesana Aniga Karangasem", e-Journal PG-PAUD Universitas Pendidikan Ganesha Jurusan Pendidikan Anak Usia Dini, Volume 2 No 1 Tahun 2014, 1.

3 Zulhannan, Teknik Pembelajaran Bahasa Arab Interaktif, (Jakarta : PT. Rajagrafindo Persada, 2015), 191.
} 
Kurang atau tidak ada partisipasi dari siswa lainnya, 4) Penggunaan Bahasa ibu, merasa tidak bisa berbicara Bahasa asing. ${ }^{4}$

Bagian terpenting dalam pembelajaran maharah kalam sendiri yang perlu diperhatikan yaitu terdapat tiga bagian, antara lain : 1) Pengucapan, 2) Kosa kata atau Mufrodat, dan yang 3) Tata Bahasa atau Qowaid . ${ }^{5}$ Ketiga bagian tersebut dikatakan penting karena tidak mungkin dalam pembelajaran maharah kalam tidak memperhatikan pengucapan atau artikulasi peserta didik. Untuk mengkombinasikan tiga bagian penting tersebut, maka kita memerlukan sebuah metode yaitu metode Ta'bir Ash-shuwar Al-'asywai.

Metode Ta'bir Ash-shuwar Al-'asywai atau dikenal dengan metode story telling dengan media gambar seri. Story Telling atau dongeng adalah cerita prosa rakyat yang tidak di anggap benar-benar terjadi. Menurut Danandjaja, dongeng diceritakan terutama untuk hiburan, walaupun banyak juga yang melakukan kebenaran, berisikan pelajaran moral, atau bahkan sindiran. ${ }^{6}$ Metode bercerita adalah salah satu metode yang dapat mengembangkan kemapuan berbahasa anak, dan membantu mengembangkan fantasi anak, dan mengembangkan nilai moral anak .Adapun tujuan dari dari bercerita menurut kemendiknas (2010) yaitu:1) melatih daya tangkap anak,2) melatih daya pikir,3) melatih daya konsentrasi anak,4) membantu perkembangan fantasia tau imajinasi anak,5) menciptkan suasana menyenangkan dan akrab.

Kemudian menurut (Muhlis Baharuddin:2018) media gambar seri adalah kumpulan dari beberapa gambar yang menceritakan suatu kejadian atau peristiwa yang menarikyang disusun secara acak, atau berurut untuk dijadikan sebuah cerita. Pendapat lain mengatakan bahwa gambar seri adalah rangkaian beberapa gambar yang disusun secara urut dan membentuk sebuah cerita yang runtut.$^{7}$ Media gambar seri ini tersusun dari kertas lebar memanjang yang berisi beberapa buah gambar, dan gambar-gambar tersebut berhubungan satu sama lain sehingga merupakan satu rangkaian cerita.

\footnotetext{
${ }^{4}$ Abdul Wahab Rosyadi, Mamluatul Ni'mah, Memahami Konsep dasar pembelajaran Bahasa Arab, 91.

5 Halimatus Sa'diyah, “ Bermain Peran (Role Playing) Dalam Pembelajaran Maharah Al-Kalam di PKPBA UIN Maliki Malang”, Jurnal Tarbiyatuna, Volume 3 No.2 (Desember), 20-22.

${ }^{6}$ Muhlis Bahruddin, " Pembelajaran Keterampilan Berbicara Bahasa Arab Melalui Pendekatan Komunikatif”, POTENSIA:Jurnal Kependidikan Islam, Vol3, No.2, Juli-Desember

${ }^{7}$ Lilis Madyawati, Strategi Pengembangan Bahasa pada Anak, (Jakarta: Pranamedia Group),208.
} 
Pembelajaran yang menerapkan metode ta'bir ash-shuwar al-'asywai merupakan metode yang berusaha untuk meningkatkan ketermapilan berbicara peserta didik. Karena dengan menerapkan gambar tersebut dapat membangkitkan rasa ketertarikan pada suatu pembelajaran maharah kalam sehingga kemampuan berbicara anak akan meningkat atau kefasihan dalam berbahas arab meningkat, dapat menumbuhkan rasa percaya diri, penanaman nilai-nilai ${ }^{8}$ Disamping itu juga Ni Komang Tendriana Merdeka Wati, A.A. Gede Agung, I Koang Sudarma dalam penelitiannya mengemukakan bahwa manfaat media gambar seri selain yang disebutkan sebelumnya juga dapat mengatasi keterbatasan pengamatan kita, dapat memperjelas suatu masalah, sehingga dapat mencegah atau membetulkan kesalahpahaman, serta ekonomis. ${ }^{9}$

Suwarti Ningsih (243), Minatul azmi dan Maulida Puspita (2019:69), dan Arie Sanjaya (2016:70) dan Chesaria Puspa Ningsih (2017:34) dalam penelitiannya masing-masing telah membuktikan bahwa metode bercerita atau story telling mampu mengembangkan atau meningkatkan keterampilan berbicara siswa, mampu meningkatkan daya tarik serta kreativitas siswa dalam pembelajaran maharah kalam serta mampu menambahkan minat, perluasan pembendaharaan kosa kata dan tata Bahasa pada siswa. Story Telling dengan bantuan media gambar seri juga dapat meningkatkan keterampilan berbicara siswa, hal ini sesuai dengan yang dikemukakan oleh Komang Uning Mahendri Ariadi, Gede Raga, Mutiara Magta (2014) dan Ni Komang Tendriana Merdeka Wati, A.A. Gede Agung, I Koang Sudarma (2014:1) dalam penelitiannya bahwa dengan menggunakan metode bercerita dengan media gambar seri atau story telling dengan media gambar seri atau Ta'bir Ash-Shuwar Al-'Asywai dapat meningkatkan perkembangan Bahasa anak terutama dalam keterampilan berbicara. Oleh karena itu, terdapat tiga pertanyaan untuk melengkapi atau menambah kajian-kajian yang sudah pernah dilakukan, yaitu : 1) bagaimana pembelajaran maharah kalam yang ada sekarang

\footnotetext{
8 Minatul Azmi, Maulida Puspita, " Metode Story Telling Sebagai Solusi Pembelajaran Maharah Kalam di PKPBA UIN Malang", Inovasi Media Pembelajaran Bahasa, Sastra, dan Budaya Arab, Seminar Nasional Bahasa Arab Mahasiswa Iii Thaun 2019 HMJ Jurusan Sastra Arab Fakultas Sastra Universitas Negeri Malang, 76-77.

${ }^{9}$ Ni Komang Tendriana Merdeka Wati, A.A. Gede Agung, I Koang Sudarma, "Penerapan Metode Bercerita dengan Media Gambar Seri untuk Meningkatkan Kemampuan Bahasa Anak pada Kelompok B2 TK Widya Kumara Ari”, e-Journal PG-PAUD Universitas Pendidikan Ganesha Jurusan Pendidikan Guru Pendidikan Anak Usia Dini (Volume 2 No 1 tahun 2014), 5.
} 
ini?, 2) bagaimana penerapan pembelajaran maharah kalam?, 3) Mengapa metode Ta'bir Ash-shuwar al-'Asywai perlu diterapkan?.

Maka dengan menggunakan metode Ta'bir Ash-shuwar Al-'Asywai ini pembelajaran akan lebih efektif dan menyenangkan. Karena metode Ta'bir Ashshuwar Al-'Asywai adalah metode yang dapat meningkatkan keterampilan berbicara, mendorong siswa memiliki kemampuan verbal. Tak hanya itu, dengan bercerita mahasiswa akan belajar tata cara berdialog dan bernarasi. Metode ini mendorong mahasiswa untuk lebih senang bercerita atau berbicara. Sedangkan gambar yang di susun secara acak tersebut merupakan media yang dapat membuat mahasiswa lebih senang dan semangat dalam pembelajaran maharah kalam. Disamping itu juga metode dan media tersebut dapat memperluas perbendaharaan kata dan tata Bahasa.

\section{METODE PENELITIAN}

Jenis penelitian ini yaitu penelitian lapangan (Field Research). Penelitian ini menggunakn pendekatan deskriptif kualitatif. Metode Penelitian Kualitatif adalah metode yang penelitiannya digunakan untuk meneliti pada kondisi obyek yang alamiah. Metode penelitian kualitatif digunakan untuk mendapat data yang mendalam, data yang sebenarnya. ${ }^{10}$ Sedangkan menurut Moleong mengartikan bahwa penelitian kualitatif adalah penelitian yang menggunakan latar alamiah, dengan maksud menafsirkan Fenomena yang terjadi dan dilakukan dengan jalan berbagai metode yang ada. ${ }^{11}$

Penelitian deskripstif kualitatif ini terdiri dari dua variable yaitu metode Ta'bir Ash-shuwar Al-'asywai dan Maharah kalam, dan digunakan untuk mendiskripsikan penerapan metode Ta'bir Ash-shuwar Al-'asywai pada pembelajaran maharah kalam mahasiswa semester III Pendidikan Bahasa Arab IAIN Madura. Kehadiran peneliti dilapangan pada saat penelitian sangat di perlukan, karena peneliti bertindak langsung untuk mengamati penelitian dan menjadi pengumpul data dan pelapor dari hasil penelitian. Lokasi yang dipilih oleh

\footnotetext{
${ }^{10}$ Sugiyono, Metode Penelitian Pendidikan Pendekatan Kuantitatif, Kualitatif, dan R\&D, (Bandung: Alfabeta, 2014), 15.

11 Tohirin, Metode Penelitian Kualitatif dalam Pendidikan dan Bimbingan Konseling, (Jakarta:PR RajaGrafindo Persada, 2012), 2.
} 
peneliti untuk melakukan penelitian tersebut yaitu pada mahasiswa semester III Jurusan Pendidikan Bahasa Arab di IAIN Madura.

Data yang di ambil pada saat penelitian yaitu melalui proses Triangulasi. Yang mana dalam teknik pengumpulan melalui Triangulasi itu merupakan teknik pengumpulan data yang bersifat menggabungkan dari berbagai teknik pengumpulan data dan sumber data yang telah ada .12 Maka penelitian mengggunakan berbagai teknik pengumpulan data yaitu observasi, wawancara dan dokumentasi. Observasi merupakan cara pengumpulan data yang dilakukan melalui suatu pengamatan, dengan disertai pencatatan terhadap keadaan suatu perilaku objek sasaran. Observasi ini dilakukan dengan cara penulis datang ke lokasi dan ikut serta dalam pembelajaran maharah kalam guna mencari data permasalahan yang dihadapi oleh mahasiswa sehingga penulis bisa menemukan solusi yaitu dnegan menrapkan metode Ta'bir Ash-shuwar Al-'asywai. Sedangkan wawancara adalah pertemuan dua orang untuk bertukar informasi dan ide melalui Tanya jawab, sehingga dikontruksikan makna dalam satu topik tertentu. Metode wawancara ini penulis gunakan untuk mendapatkan informasi dari dosen pengampu dan mahasiswa PBA semester III terkait pembelajaran maharah kalam. Dan yang terakhir adalah dokumentasi, dokumentasi merupakan catatan peristiwa yang sudah berlalu. Dokumen bisa berbentuk tulisan, gambar, atau karya-karya dari seseorang.

Sedangkan sumber data adalah subjek dari mana data dapat diperoleh. ${ }^{13}$ Maka, sumber data yang diambil pada penelitian ini adalah 34 mahasiswa semester III Jurusan Pendidikan Bahasa Arab IAIN Madura.

Teknik analisis data yang dipakai dalam penelitian ini adalah analisis data Model Miles and Huberman. Yang mana menurut Model Miles and Huberman dalam menganalisis data itu di mulai dari data reduction, data display, dan conclusion drawing/verification. ${ }^{14}$ Reduksi data merupakan proses berfikir sensitif yang memerlukan kecerdasan dan keluasan dan kedalaman wawasan yang tinggi. Dan dengan reduksi, maka peneliti merangkum, mengambil data yang pokok dan penting. Setelah data direduksi, maka langkah selanjutnya adalah mendisplaykan data. Yang mana dalam penelitian kualitatif, penyajian data bisa dilakukan dalam

\footnotetext{
${ }^{12}$ Sugiono,...,241.

${ }^{13}$ Suharsimi Arikunto, Prosedur Penelitian, (Jakarta : Pt. Rhineka Cipta, 2002), 107.

${ }^{14}$ Sugiono, Metode Penelitian...,246.
} 
bentuk uraian singkat, bagan, hubungan antar kategori, Flowchart, dan sejenisnya, yang gunanya agar dapat memudahkan untuk memahami apa yang terjadi, merencanakan kerja selanjutnya berdasarkan apa yang telah difahami tersebut. Langkah ketiga dalam analisis data menurut Miles and Huberman adalah penarikan kesimpulan dan verifikasi.

\section{HASIL PENELITIAN}

Penelitian ini dilaksanakan pada Mahasiswa semester III pada jurusan pendidikan Bahasa Arab di salah satu kampus di Madura yaitu IAIN Madura. Di IAIN Madura, khusunya pada jurusan pendidikan Bahasa arab, pembelajaran maharah hanya di ajarkan pada semester tiga saja, baik maharah kalam (keterampilan berbicara), maharah istima' (keterampilan mendengar), maharah kitabah (keterampilan menulis), dan maharah qiroah (keterampilan membaca). Akan tetapi, peneliti hanya fokus pada pembelajaran maharah kalam saja. Mengapa memilih maharah kalam? karena peneliti ingin melihat sejauh mana kemampuan mahasiswa pendidikan Bahasa arab semester III dalam berbicara Bahasa arab walaupun dari latar belakang pendidikan yang berbeda-beda. Setelah melakukan observasi pada pertemuan pertama, maka mahasiswa tersebut masih merasa malu, merasa takut, dalam berbicara di depan kelas dengan berbahasa Arab, walaupun dosen pengampu dari pembelajaran maharah kalam tersebut telah menggunakan berbagai metode agar mahasiswa tidak merasa jenuh. Akan tetapi, mahasiswa tetap merasa jenuh, takut, dan malu untuk berbicara. Oleh karena itu, si peneliti berinisiatif untuk mencari metode dan media yang mana antara pengajar dan mahasiswa sama-sama aktif yaitu dengan memilih metode Ta'bir Ash-shuwar Al-'asywai (metode story telling dengan media gambar seri). Jadi, pada pertemuan pertama ini peneliti hanya mengamati bagaimana sitem pembelajaran yang dilakukan oleh dosen pengampu pada mata kuliah Maharah Kalam, dan mengamati kelemahan-kelemahan yang masih ada pada mahasiswa.

Dari kelemahan-kelemahan tersebut, maka peneliti menerapkan metode Ta'bir Ash-shuwar Al-'asywai, pada pertemuan kedua. Dalam metode ini, mahasiswa di tuntut untuk bisa bekerjasama sesama teman, dan dituntut untuk bisa mukalamah dengan menceritakan gambar yang telah di susun. Berikut tahapan-tahapan dalam pembelajaran maharah kalam menggunakan metode Ta'bir Ash-shuwar Al-'asywai : 
Pertama, Pada tahap ini guru melakukan persiapan dengan menyiapkan gambar yang akan dijadikan bahan, kemudian gambar tersusun di acak agar mahasiswa bisa menyusunnya membentuk sebuah cerita. Kemudian gambar tersebuat di masukkan ke dalam amplop.

Kedua, Guru membagi kelompok. Meskipun metode tersebuat memungkinkan untuk dikerjakan individu, akan tetapi kita harus melihat waktu yang tersedia. Guru membagi menjadi 7 kelompok sesuai dengan jumlah murid yang ada yaitu 34 mahasiswa. Jadi, guru membaginya ke dalam 7 kelompok dan setiap kelompok 5 orang dan ada satu kelompok yang tediri dari 4 orang.

Ketiga, Guru membagikan amplop-amplop tersebut yang telah terisi gambar fable ke setiap kelompok yang telah dibagi sebelumnya. Kemudian guru menjelaskan langkah-langkah tugas yang harus dikerjakan oleh mahasiswa.

Keempat, mahasiswa menyusun gambar yang telah diacak menjadi sebuah cerita, kemudian menentukan judul dari cerita tersebut. Dan mahasiswa menempelkan gambar yang telah tersusun tersebuat di kertas karton dan menuliskan ceritanya di bawah gambar tersebut.

Kelima, guru memilih perwakilan setiap kelompok secara acak untuk mendiskripsikan atau menceritakan gambar yang telah di susun di depan kelas, tanpa melihat cerita yang telah di tulis di kertas karton tersebut.

Keenam, guru memilih kelompok terbaik dari semua kelompok dengan memberikan hadiah bagi yang terbaik tersebut.

Peneliti memilih metode dan media ini, karena menurut peneliti metode tersebut sangat cocok untuk meningkatkan keterampilan berbicara mahasiswa dengan latar belakang yang berbeda-beda. Dan dengan metode dan media ini, dapat membantu psikologis mahasiswa. Artinya menghilangkan rasa takut, rasa malu dalam berbicara Bahasa Arab. Karena selain siswa yang aktif dalam metode ini, pengajar pun ikut aktif agar tidak ada kecanggungan, sehingga akan tumbuh keberanian mereka dalam berbicara Bahasa arab. Hal itu terbukti setelah observasi pertama yng dilakukan peneliti, setelah melihat kelemahan-kelemahan pada mahasiswa semester III tersebut. Karena pada kelas tersebut tidak hanya dari alumni pondok pesantren semua, namum ada sebagian yang berlatar pendidikan dari sekolah negeri yang hanya sebatas mengenal Bahasa arab secara mendasar saja. Dan hal itu, terbukti dengan menerapkan metode tersebut, peserta didik 
menjadi lebih semangat dan kelamahan-kelemahan bisa tertutupi. Dan hal itu, diketahui pada pertemuan ketiga, saat mereka mengerjakan tugas yang diberikan peneliti, kemudian saat mereka menceritakan gambar yang telah di susunnya, mereka sudah bisa menceritakan dengan menggunakan Bahasa arab tanpa rasa takut, malu, dan lain sebagainya. Dan kesalahan-kesalahan baik dari segi qowaid, mufrodat yang di alaminya selama ini mulai berkurang.

\section{PEMBAHASAN}

Nirmala Fildza Farkhana dalam penelitiannya menyebutkan bahwa dalam mempelajari Bahasa terutama Bahasa asing akan banyak problematika yang akan dihadapi oleh peserta didik. Kemudian interaksi dalam proses pembelajaran baik peserta didik dengan pendidik mempunyai peran yang sangat penting. ${ }^{15}$ Oleh Karena itu, dalam mengajar harus memperkaya metode agar tercipta interaksi dan proses pembelajaran berjalan dengan baik. Utamanya dalam proses pembelajaran kebahasaan, dan keterampilan yang terpenting dalam kebahasaan itu adalah keterampilan berbicara atau Maharah Kalam. Dan faktor yang menghalangi dalam maharah kalam sendiri yaitu rasa takut salah dan malu. Dan berdasarkan hasil observasi hal seperti itu, terjadi pada mahasiswa PBA semester III di IAIN Madura. Kendala yang dialami mereka selain karena keterbatasan mufrodat atau kosakata yang mereka ketehui, yaitu mereka takut saat mereka berbicara menggunakan Bahasa arab salah baik dari qowaidnya, dan lain-lain.

Dalam pembelajaran maharah kalam, pengajar sudah menerapkan berbagai macam metode, hanya saja mahasiswa masih merasa malu untuk berbicara menggunakan Bahasa Arab. Kemudian mahasiswa juga belum mampu berinterkasi sesama temannya. Oleh karena itu, si peneliti mempunyai inisiatif untuk memilih salah satu metode yang bisa membuat mahasiswa bisa saling berinteraksi dan aktif dalam pembelajaran maharah kalam. Maka dari itu si peneliti, meneliti tentang penerapan metode Ta'bir Ash-shuwar Al-'asywai atau lebih di kenal dengan story telling menggunakan media gambar seri. Dengan bercerita, bisa mengatasi masalah Mahasiswa PBA IAIN Madura yang salah satunya yaitu keterbatasan kosa kata. Maka dari itu, dengan bercerita dapat memperluas

\footnotetext{
${ }^{15}$ Nirmala Fildza Farkhana, “ Pembelajaran Maharah Al Kalam Siswa Kelas Unggulan Di MTS N 2 Banjarnegara Tahun Pelajaran 2016/2017” (Skripsi-IAIN PURWOKERTO, Purwokerto, 2017), 1
} 
kosa kata, melatih visualisasi, kemampuan melihat dan menjadikan seperti gambar semua pengalamannya. ${ }^{16}$

Bahan-bahan cerita dapat diambilkan dari cerita-cerita daerah yang berupa dongeng, fable, legenda, dan lain-lain, serta lingkungan sekitarnya. Isi cerita hendaknya yang pendidikan dan menambahkan nilai-nilai keimanan dan budi pekerti luhur serta membangkitkan motivasi siswa untuk giat belajar dan bekerja. ${ }^{17}$ Dan tema dalam story telling dengan media gambar seri yang diaplikasikan pada Mahasiswa PBA semester III di IAIN Madura tersebut yaitu cerita fable "Sikancil Mencuri Timun". Cerita tersebut termasuk pada cerita fable yang mengandung pesan tersirat di dalamnya, yang mana dalam akhir cerita, mahasiswa di suruh untuk menyampaikan makna yang tersirat tersebut.

Ada beberapa macam model bercerita yang dapat dipergunakan, antara lain :1) model bercerita dengan alat peraga,2) model bercerita dengan alat peraga langsung,3) model bercerita dengan gambar,4) model bercerita dengan papan flannel, dan5) model bercerita dengan membacakan cerita (story reading) ${ }^{18}$. Dan dalam pembelajaran maharah kalam di IAIN Madura dengan metode bercerita, menggunakan model bercerita dengan gambar. Adapun tujuan dari dari bercerita menurut kemendiknas (2010) yaitu:1) melatih daya tangkap anak,2) melatih daya pikir,3) melatih daya konsentrasi anak,4) membantu perkembangan fantasia tau imajinasi anak,5) menciptkan suasana menyenangkan dan akrab. Oleh karena itu, pengajar dalam pembelajaran maharah kalam tersebut memilih metode bercerita agar dapat melatih konsentrasi mahasiswa, melatih daya pikir, mengembangkan daya imajinasnya dan melatih daya tangkap mahasiswa. ${ }^{19}$

Ada beberapa tahapan dalam bercerita dengan media gambar seri yaitu : 1) membagi beberapa kelompok dan menyiapkan tempat serta mengondisikan dengan agar tenang, 2) menunjuk delegasi kelompok untuk maju kedepan dan menyiapkan diri sebaik mungkin untuk bercerita, menguasai masing-masing alur, dan lain-lain, 3) memulai bercerita jika sudah tenang, 4) menyampaikan cerita bagian demi bagian, 5) dalam bercerita, pembawa cerita dapat sesekali terbantu dengan membaca alur cerita yang sudah di tulis di bawah gambar yang sudah

\footnotetext{
16 Subyantoro, Pembelajaran Bercerita (Yogyakarta:Penerbit Ombak, 2013), 35

17 Subyantoro, Pembelajaran Bercerita , 37

${ }^{18}$ Subyantoro, Pembelajaran Bercerita , 38.

${ }^{19}$ Lilis Madyawati, Strategi Pengembangan Bahasa pada Anak, 213.
} 
tersusun, dan 6) mengakhiri cerita dengan menyimpulkan . ${ }^{20}$ Sedangkan teknik bercerita dengan gambar seri yaitu meengatur setting tempat duduk, memotivasi agar anak mau menyimak cerita, menunjukkan gambar seri dan memulai bercerita dan ketika orang tua/pendidik bercerita, gambar ditunjukkan secara berurutan dan bergantian. ${ }^{21}$

Seperti yang telah dibahas pada hasil penelitian langkah-langkah dalam pembelajaran maharah kalam di IAIN Madura menggunakan metode Ta'bir ashshuwar al-'asywai atau Story Telling dengan media gambar sebagai berikut : 1) persiapan, 2)pembagian kelompok, 3) membagikan tugas, 4)menyusun gambar, 5) perwakilan setiap kelompok untuk menceritakan gambar yang telah disusun, 6) mengakhiri dengan memilih kelompok terbaik.

Berdasarkan pada penelitian dengan menerapkan metode ta'bir ashshuwar al-'asywai, peneliti mendapatkan beberapa temuan dari penelitian tersebut. Diantaranya, yang pertama dengan menerapkan metode tersebut dengan media gambar yang di susun secara acak, mahasiswa menjadi lebih kompak dalam bekerjasama dengan kelompok. Kemudian yang kedua, mahasiswa lebih aktif dan bersemangat dalam pembelajaran maharah kalam, karena mereka berlombalomba untuk membuat kelompok mereka masing-masing menampilkan yang terbaik dengan cara menceritakan gambar yang sudah di berikan dengan baik dan benar.

Dalam proses pembelajaran dengan menggunakan metode dan media gambar seri tersebut, siswa terlihat bersemangat dan tertarik untuk mengikuti pembelajaran maharah kalam. Para mahasiswa sangat berantusias dalam proses pembelajaran tersebut, karena selain untuk melatih keterampilan berbicara mahasiswa, juga pembelajaran dengan metode Ta'bir Ash-shuwar Al-'asywai melatih mahasiswa untuk bekerjasama dalam berkelompok. Metode dan media ini merupakan sebuah metode yang melibatkan gambar seri, artinya gambar tersebut di acak kemudian di susun sehingga menjadi sebuah cerita. Tema dari media gambar tersebut bervariasi, sehingga membuat mahasiswa bersemangat dalam pembelajaran maharah kalam tersebut. Oleh karena itu, pembelajaran yang dilengkapi dengan media akan menjadi pembelajaran yang efektif di dalamnya dan

${ }^{20}$ Idem, 212. 
dapat mengatasi sikap pasif peserta didik. Tujuan dari media gambar seri yaitu:1) dapat meningkatkan kemampuan bercerita,2) dapat meningkatkan kemampuan dalam memahami isi gambar tersebut,3) akan lebih menarik dan bervariasi karena menggunakan media gambar dengan berbagai warna, 4) dapat mengembangkan keterampilan berbicara. ${ }^{22}$

Jadi, hal demikian didukung oleh ungkapan tentang beberapa kegunaan media pembelajarana yaitu, menimbulkan semangat belajar, memungkinkan interaksi yang lebih langsung antara peserta didik dengan lingkungan dan kenyataan, memungkinkan peserta didik belajar sendiri-sendiri menurut kemampuan dan minatnya, memudahkan untuk menggali informasi yang dibutuhkan.$^{23}$

Dengan adanya penerapan metode dan media tersebut, mahasiswa menjadi lebih berani untuk berbicara menggunakan Bahasa Arab, karena dalam media tersebut siswa dianjurkan untuk saling bekerjasama dan lebih aktif dalam berbicara. Keberanian mahasiswa dan keaktifan mahasiswa dalam pembelajaran dapat dilihat dari hasil observasi yang dilakukan oleh peneliti pada mahasiswa semester III jurusan pendidikan Bahasa Arab. Hasil dari obeservasi tersebut menyatakan bahwa hamper semua mahasiswa menyukai pembelajaran maharah kalam menggunakan metode dan media tersebut. Sedangkan ada beberapa mahasiswa yang hasilnya tetap tidak berubah dikarenakan factor dari psikis yang memang susah untuk bergaul dan selalu malu untuk berbicara. Dengan demikian, dapat disimpulkan bahwa dalam pembelajaran maharah kalam menggunakan metode Ta'bir Ash-shuwar Al-'asywai dapat meningkatkan keterampilan bebicara pada mahasiswa semester III Pendidikan Bahasa Arab di IAIN Madura.

\section{KESIMPULAN}

Dalam metode Ta'bir Ash-shuwar Al-'asywai ini, mahasiswa situntuk untuk bisa berbicara bahasa arab tanpa memeperhatikan rasa takut, ras malu, dan lain sebagainya. Terdapat beberapa tahapan dalam penerapan metode ini, yaitu persiapan, membagi kelompok, menyusun gambar, menempel gambar, dan menceritakan kembali gambar yang telah disusun.

\footnotetext{
${ }^{22}$ Lilis Madyawati, Strategi Pengembangan Bahasa Pada Anak, 209.

${ }^{23}$ Abdul Wahab Rosyidi, Media Pembelajaran Bahasa Arab, (Malang : UIN Maliki Press, 2017),32.
} 
Oleh karena itu, berdasarkan temuan penelitian dan pembahasan dapat disimpulkan bahwa penerapana metode Ta'bir Ash-shuwar Al-'asywai atau Story telling dengan medi gambar seri pada pembelajaran maharah kalam mahasiswa semester III Juruasan Pendidikan Bahasa Arab di IAIN Madura berjalan dengan baik. Keinginan dan kesemangatan mahasiswa dalam pembelajaran maharah kalam dengan menerapkan metode tersebut sangat terlihat dan ketertarikan mereka dalam pembelajaran maharah kalam dengan adanya media gmabar seri tersebut. Proses pembelajaran sendiri berjalan dengan sangat baik dan lancar. Para mahasiswa sangat berantusias dan lebih bersemangat untuk mengikuti prose pembelajaran maharah kalam tersebut. Selain itu, juga membuat mahasiswa dapat lebih bersosialisasi antar sesame teman dan saling bekerjasama sesuai kelompok masing-masing. Kemudia metode dan media tersebut membuat siswa lebih termotivasi untuk tidak malu dan tidak takut salah dalam berbicara menggunakan Bahasa Arab, dan mahasiswa juga lebih aktif dalam pembelajaran maharah kalam dengan penerapan metode Ta'bir Ash-shuwar Al-'asywai.

Penulis berharap penelitian ini bisa bermanfaat bagi semua pihak ataupun semua orang, baik dari pihak pengajar maupun pembelajar. Karena dalam proses pembelajaran membutuhkan strategi, metode ataupun media, agar proses pembelajaran tersebut menjadi pembelajaran yang kreatif dan inovatif. Oleh karena sebagai pendidik, terutama dalam bidang kebahasaan harus memperkaya metode agar tidak terjadi kejenuhan dalam proses pembelajaran tersebut. Dan dikhususkan lagi pada pembelajaran maharah kalam, yang mana merupaka keterampilan yang paling penting dalam kebahasaan. Penulis juga berharap adanya penelitian lanjutan sebagai pengembangan dari penelitian ini dan penulis juga berharap adanya kritik dan saran dari pembaca. Karena penulis menyadari akan banyaknya kesalahan, kekurangan bahkan kekeliuran yang dilakukan oleh peneliti.

\section{DAFTAR PUSTAKA}

Arikunto, Suharsimi, , Prosedur Penelitian, Jakarta: PT. Rhineka Cipta, 2002.

Azmi, Minatul, Maulida, Puspita, Metode Stori Telling Sebagai Solusi Pembelajaran Maharah Kalam di PKPBA UIN Malang, Inovasi Media pembelajaran Bahasa, sastra, dan Budaya Arab, Seminar Nasional Bahasa Arab Mahasiswa III Tahun 
2019 HMJ Jurusan sastra Arab Fakultas sastra Universitas Negeri Malang, 2019

Baharuddin,Muhlis, Penerapan Metode Story Telling (Mendongeng) Dengan Media Gambar Seri Untuk Meningkatkan Keterampilan Berbicara SIswa Kelas II SDN 1 Pringgabaya Tahun Ajaran 2017/2018, Jurnal Skripsi : Universitas Mataram ,2018.

Farkhana, Nirmala Fildza, 2017, Pembelajaran Maharah Al-Kalam Siswa Kelas Unggulan Di MTS N 2 Banjarnegara Tahun Pelajaran 2016/2017, Skripsi.

Madyawati, Lilis, Strategi Pengembangan Bahasa pada Anak, Jakarta: Pranamedia Group, 2016.

Puspa Ningsih, Chaesaria, Peningkatan Kemampuan Berbicara Melalui Metode Bercerita Disertai Media Gambar Pada Anak Kelompok B TK Kusuma Pugeran Suryodiningratan Yogyakarta, Jurnal Pendidikan Anaka Usia Dini Edisi 1 Tahun ke-6, 2017.

Rosyidi, Abd.Wahab, Mamlu'atul Ni'mah, Memahami Konsep Dasar Pembelajaran Bahasa Arab, Malang: UIN Maliki Press, 2011.

Rosyadi, Abdul Wahab, Media Pembelajaran Bahasa Arab, Malang: UIN Maliki Press, 2017.

Sa'diyah, Halimatus, Bermain Peran (Role Playing) Dalam Pembelajaran Maharah Al-Kalam di PKPBA UIN Maliki Malang, Jurnal Tarbiyatuna Volume 3 No 2 (Desember) , 2018.

Subyantoro, Pembelajaran Bercerita, Yogyakarta: Penerbit Ombak, 2013.

Sugiyono, Metode Penelitian Kuantitatif, Kualitatif, dan R\&D, Bandung: Alfabeta, 2016.

Tohirin, Metode Penelitian Kualitatif dalam Pendidikan dan Bimbingan Konseling, Jakarta:PR RajaGrafindo Persada, 2012.

Wahyuni, Ni Kd. Dewi, Wyn. Wiarta, Ngh. Suadnyana, Penerapan Metode Bercerita Berbantuan Media Gambar Seri Untuk Meningkatkan Keterampilan Berbicara Anak Kelompok B TK Putra Sesana Antiga Karangasem, e-Journal PG-PAUD Universitas Pendidikan Ganesha Jurusan Pendidikan Guru Pendidikan Anak Usia Dini ,Volume 2 N0 1 tahun 2014.

Zulhannan, Teknik Pembelajaran Bahasa Arab Interaktif, Jakarta: PT. Rajagrafindo Persada, 2015. 